\title{
Digital Competitiveness of European Union Member States from the Perspective of Human Capital
}

\author{
Victoria Folea \\ Institute of World Economy, Romanian Academy \& Romanian-American University
}

\begin{abstract}
The concepts of "digital skills" and "digital competences" are key terms in the discussion related to the type of skills people need nowadays not only in terms of digital inclusion in the society but also in terms of employability. According to the latest definition by the European Union, digital skills "can be broadly understood as the ability to locate, organise, understand, evaluate, create and share information using digital technology, at different levels of competence" (European Commission, 2017). The rapid development of information and communication technologies (ICT) bring major transformations with respect to the individual's integration in society and employability. The paper analyses the 28 member states of the European Union (EU) from the perspective of the pesons' digital skills and employability in the science, technology (including the ICT) sectors over the period 2015 - 2017. The paper covers the following areas of research: (1) Overall digital skills, computer skills, internet skills of individuals in the EU 28; (2) Human capital with advanced and specialist digital skills in ICTin the EU 28; (3) Evolution of the digital competitiveness of the EU 28 member states from the perspective of human capital over the period 2015-2017. Quantitative and qualitative research methods were employed for data collection and analysis: database research and analysis; statistical analysis; content and thematic research and analysis from policy papers and reports.
\end{abstract}

Keywords: digital economy; digital society; digital skills; information and communication technologies

\section{Introduction}

In May 2017, the European Commission published a study regarding the use of IT / digital technologies in the workplaces in the EU, looking more closely at the digital skills required and currently existent (European Commission, 2017). As the information and communication (digital) technologies are more and more used by companies and organizations across the world, and thus the jobs are becoming partially or totally digital, the requirements imposed on the workers' skills are changing (Burton, 2015), (Digital Technology, 2017). It becomes evident for employers that an effective and efficient use of the digital technologies in the workplace must be accompanied by appropriate digital competences of the workforce. Equally, the daily life becomes more and more connected to information and communication (digital) technologies, and we all seem to need certain digital competences, even at basic level.

The concepts of "digital skills" and "digital competences" are becoming key terms in the discussion related to the type of skills people need nowadays not only in terms of digital inclusion in the society but also in terms of employability (European Commission, 2016), (Ferrari, 2013), (M. Kolding, C. Robinson, M. Ahorlu, 2009), (R. Vuorikari, Y. Punie, S. Carretero, L. Van den Brande, 2016).

Until now there is, however, no common definition agreed upon for digital skills or digital competences. Different terms with sometimes different interpretations are currently used in literature, with the general understanding that they refer to the 
abilities of using information and communication technologies, such as: IT literacy, ICT literacy, digital literacy, digital competence, ICT fluency, computer literacy, ICT skills, e-Skills, technological literacy, media literacy, information literacy, e-literacy (Chinien - Boutin, 2013). The first definitions used referred to "ICT literacy" as knowledge about computer use (J. Fraillon, W. Schulz, J. Ainley, 2013). As information and communication technologies become more complex and new applications develop, broader definitions emerged covering cognitive, attitudinal, social and emotional skills. Over time, a range of (sometimes partially) overlapping definitions, such as computer literacy, internet literacy, media literacy and digital literacy, has emerged (K.A.Mutka, 2011). In 2006, the European Commission adopted the definition of "digital competence" as "the confident and critical use of ICT for work, leisure, learning and communication", recognising it as one of eight key competences for lifelong learning (European Parliament and Concil of the EU, 2006), however this concept is still fluid, susceptible to additions and modifications, continuously expanding and changing as a consequence of the rapid evolution of information and digital technologies (L. Ilomaki, A. Kanotsalo, M. Lakkala, 2011).

\section{Overall digital skills, computer skills, internet skills of individuals}

The study of literature (policy documents, academic literature and learning practices) revealed the existence of several conceptual framework for digital skills and components, which have a twofold objective: (1) the assessment and measurement of digital competences and (2) understanding the development of digital competences among citizens ( $\mathrm{Y}$. Eshet-Alkalai, E. Chajut, 2010), (OECD, 2013), (Ecorys UK, 2016). The EU Digital Agenda for Europe, which envisaged the development of "EU-wide indicators of digital competence and media literacy", led to the development of the DigComp framework on digital competence (European Commission, 2010), which was designed to help policymakers formulate appropriate education and lifelong learning policies.

Surveying the literature, it is possible to identify three main categories of digital skills, which can be found in different frameworks for the measurement or development of digital competences. These three categories apply to different types of abilities and users (European Commission, 2017):

"a). Basic digital literacy skills allow individuals to become digitally literate; these skills can be applied both to the workforce and generally to individuals in knowledge and digital society;

b). Digital skills which relate to employment, encompassing basic skills plus skills which are needed in a workplace and generally are linked to the use of ICT applications developed by professionals of information technology;

c). Digital skills for ICT professions, which include both categories above and the skills needed in the ICT sector as well as having an innovative and creating component, as linked to the ability to develop new digital solutions, products or services."

Among the conceptual frameworks that manage the digital skills, a number of them focused on individual skills, needed in everyday life including employment (i.e. basic digital literacy skills and digital skills which relate to employment from above), however more such frameworks only looked at the skills of ICT workforce. Table 1 summarises the most used conceptual frameworks for generic, specialist and complementary digital skills.

\section{Table 1. Conceptual frameworks for digital skills}

\begin{tabular}{|l|l|}
\hline Reference & Digital skills framework \\
\hline $\begin{array}{l}\text { European e-Skills Forum - } \\
2004 \\
\text { (European Commission, } \\
2017)\end{array}$ & $\begin{array}{l}\text { ICT user skills, required for effective use of ICT systems and devices; "ICT users apply systems as } \\
\text { tools in support of their own work, which is, in most cases, not ICT"; } \\
\text { ICT practitioner skills, required for researching, managing, developing and designing, consulting, } \\
\text { marketing and selling, integrating, installing and administering, maintaining, servicing ICT systems; } \\
\text { E-business skills (or e-leadership skills), needed to exploit opportunities provided by ICT, producing } \\
\text { more efficient and effective performance of different types of organisations, exploring possibilities for } \\
\text { new ways of conducting business and organisational processes, establishing new enterprises. }\end{array}$ \\
\hline $\begin{array}{l}\text { OECD's Skills for the Digital } \\
\text { Economy - 2004 } \\
\text { (OECD, 2004) }\end{array}$ & $\begin{array}{l}\text { ICT specialists: user whose competences cover the "ability to develop, operate and maintain ICT } \\
\text { systems". ICTs make up for the main part of their job; } \\
\text { Advanced users: this group of users are "competent users of advanced, and often sector-specific, } \\
\text { software tools". ICT is a tool in a workplace context; } \\
\text { Basic users: basic users are "competent users of generic tools (e.g. office software, e-mailing and }\end{array}$ \\
\hline
\end{tabular}




\begin{tabular}{|c|c|}
\hline Reference & Digital skills framework \\
\hline & other internet-related tools) needed for the information society, e-government and working life". \\
\hline $\begin{array}{l}\text { European eCompetence } \\
\text { Framework (e-CF) - } \\
\text { (European e-Competenece } \\
\text { Framework, 2016) }\end{array}$ & $\begin{array}{l}\text { "Dimension 1: } 5 \text { e-Competence areas, derived from the ICT business processes Plan, Build, Run, } \\
\text { Enable and Manage; } \\
\text { Dimension 2: A set of reference e-Competences for each area, with a generic description for each } \\
\text { competence. Forty competences identified in total provide the European generic reference definitions } \\
\text { of the e-CF 3.0.; } \\
\text { Dimension 3: Proficiency levels of each e-Competence provide European reference level specifications } \\
\text { on e-Competence levels e-1 to e-5 that are related to the EQF levels } 3 \text { to 8; and } \\
\text { Dimension 4: Samples of knowledge and skills relate to e-Competences in Dimension 2. They are } \\
\text { provided to add value and context and are not intended to be exhaustive". }\end{array}$ \\
\hline $\begin{array}{l}\text { Cedefop European Skills } \\
\text { and Jobs (ESJ) survey - } \\
2015 \\
\text { (Cedefop, 2015) }\end{array}$ & $\begin{array}{l}\text { Basic ICT skills: using a PC, tablet or mobile device for email, internet browsing; } \\
\text { Moderate ICT skills: Word-processing, using or creating documents and/or spreadsheets; } \\
\text { Advanced ICT skills: Developing software, applications or programming; use computer syntax or } \\
\text { statistical analysis packages. }\end{array}$ \\
\hline $\begin{array}{l}\text { OECD - } 2016 \\
(\text { OECD , 2016) }\end{array}$ & $\begin{array}{l}\text { "ICT specialist skills [are those necessary] to programme, develop applications and manage networks; } \\
\text { ICT generic skills [are those necessary]to use such technologies for professional purposes; } \\
\text { ICT complementary skills [are those necessary] to perform new tasks associated to the use of ICTs at } \\
\text { work, e.g. communicate on social networks, brand products on e-commerce platforms or analyse big } \\
\text { data". Complementary skills are thus "skills that are not related to the capability to use the technology } \\
\text { effectively but to carry out the work within the new environment shaped by ICTs, i.e.: a "technology-rich } \\
\text { environment"' }\end{array}$ \\
\hline $\begin{array}{l}\text { Basic digital skills framework } \\
\text { - } 2017 \\
\text { ("Prishtina"sh.a, March } \\
\text { 2013) }\end{array}$ & $\begin{array}{l}\text { Managing information: Find, manage and store digital information and content } \\
\text { Communicating: Communicate, interact, collaborate, share and connect with others } \\
\text { Transacting: Purchase and sell goods and services; organise your finances; register for and use digital } \\
\text { government services } \\
\text { Problem solving: Increase independence and confidence by solving problems using digital tools, and } \\
\text { finding solutions } \\
\text { Creating: Engage with communities and create basic digital content }\end{array}$ \\
\hline $\begin{array}{l}\text { Digital Competence } \\
\text { Framework for Citizens } \\
\text { (DigComp) - } 2017 \\
\text { (S. Carretero, R. Vuorikari, } \\
\text { Y. Punie, 2017) }\end{array}$ & $\begin{array}{l}\text { Dimension } 1 \text { and } 2 \text { represent a conceptual reference model identifying the areas to be part of digital } \\
\text { competence and the competence descriptors that belong to each area. } \\
\text { https://ec.europa.eu/digital-single-market/en/desirelate to the levels of proficiency for each competence } \\
\text { and to examples of knowledge and skills applicable to the competences }\end{array}$ \\
\hline $\begin{array}{l}\text { Development Economics - } \\
2013 \\
\text { (Development Economics, } \\
\text { 2013) }\end{array}$ & $\begin{array}{l}\text { "Advanced digital skills: skills linked to 'the creation and/or strategic exploitation of new digital } \\
\text { applications, including more advanced programming and coding involved in the creation of new } \\
\text { software, etc., but they also cover the strategic business skills needed to convert ideas into successful } \\
\text { commercial projects and ventures'; } \\
\text { Intermediate-level digital skills: these involve 'skills needed to implement and manage on a dayto-day } \\
\text { basis the applications developed by those with advanced skills, but they may also provide contributions } \\
\text { to the development of digital content, provision of system support and maintenance, etc.'; } \\
\text { Entry-level digital skills: skills related to 'the use of digital applications designed, developed and } \\
\text { promoted by others: involving for example searches for and/or the capturing and recording of digital } \\
\text { data across a wide variety of business and public services, the administration of databases, the } \\
\text { monitoring of data, contributing to the management of digital content, etc.'." }\end{array}$ \\
\hline $\begin{array}{l}\text { UKforCE - } 2014 \\
\text { (UKforCE, 2014) }\end{array}$ & $\begin{array}{l}\text { "Digital Muggle: No digital skills required - digital technology may as well be magic; } \\
\text { "Digital Citizen: the same work skills as are required to be a full digital citizen. This is the ability to use } \\
\text { digital technology purposefully and confidently to communicate, find information and purchase } \\
\text { goods/services; } \\
\text { "Digital Worker: substantially more digital skills than those required for full digital citizenship but less } \\
\text { than those of a Digital Maker. This includes, at the higher end, the ability to evaluate, configure, and } \\
\text { use complex digital systems. Elementary programming skills such as scripting are often required for } \\
\text { these tasks; and }\end{array}$ \\
\hline
\end{tabular}




\begin{tabular}{|l|l|}
\hline Reference & Digital skills framework \\
\hline & "Digital Maker: skills to actually build digital technology (typically software development). The Digital \\
Maker category is interpreted quite broadly to include, at the low end, for example, workers who \\
regularly create complex Excel macros or data files for controlling 3D printers"”
\end{tabular}

There are many computer and internet skills identified and measured at EU level. For example, Eurostat lists 37 computer skills and 19 internet skills when measuring individual's level of competence (Eurostat, 2017a), (Eurostat, 2017b). In accordance with the OECD classification of basic, advanced and specialist digital skills mentioned by OECD (OECD, 2004) , the computer and internet skills that are measured at EU level refer to low and basic activities (such as using a mouse to launch an internet browser or word processor; copying or moving files or folders; using word processing software; using copy and cut and paste tools to duplicate or move information on screen; using a search engine to find information; sending an email with attached files; create a spreadsheet (e.g. Excel); communicate through ICT using email, social media, Skype/videocalls), advanced activities (for example, writing a code in a programming language; use software for design, calculation or simulation; programme and use CNC machines ${ }^{1}$; programme and use robots) and specialist activities (for example, programming and software development; design and maintain ICT architecture for the workplace, connecting computers to a local area network) (European Commission, 2017).

In terms of overal digital skills, on average $29 \%$ of individuals in the EU 28 have above basic overal digital skills over the period 2015 - 2017 (28\% in 2015; 29\% in 2016; 31\% in 2017), the highest values in 2017 (above the EU 28 average) being reported by Luxembourg (55\%), Netherlands (48\%), Denmark (47\%), Sweden (46\%), United Kingdom (46\%), Finland (45\%), Malta (38\%), Germany (37\%), Austria (36\%), Estonia (35\%), Slovakia (33\%) and Spain (32\%) (Eurostat, 2018a). The highest increase in above basic overal digital skills among individuals between 2015 and 2017 were registered for Sweden (from $35 \%$ of individuals in 2015 to $46 \%$ of individuals in 2017) and Slovakia (from $26 \%$ of individuals in 2015 to $33 \%$ of individuals in 2017). At the other end of the scale, 1\% of individuals in the EU 28 member states have no digital skills (average between 2015 and 2017), whilst $24.6 \%$ of individuals are reported with low basic digital skills on average during 2015-2017 (Eurostat, 2018a) (Figure 1).

In 2017, the top performing EU countries in terms of percentage of population having basic digital skills were Czech Republic, Cyprus, Netherlands (Figure 2).

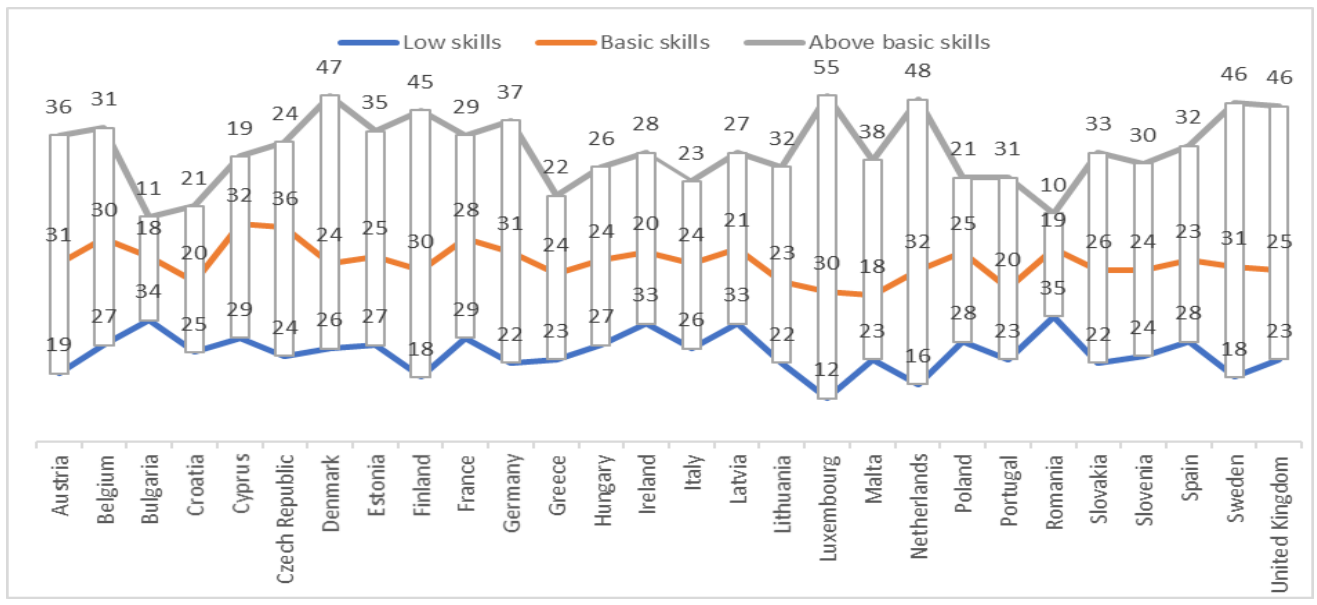

Figure 1. Overall digital skills of individuals in the EU28 in 2017 (percentage of population)

${ }^{1}$ Computer numerical control (CNC), https://en.wikipedia.org/wiki/Numerical_control 
(Source: (Eurostat, 2018a))

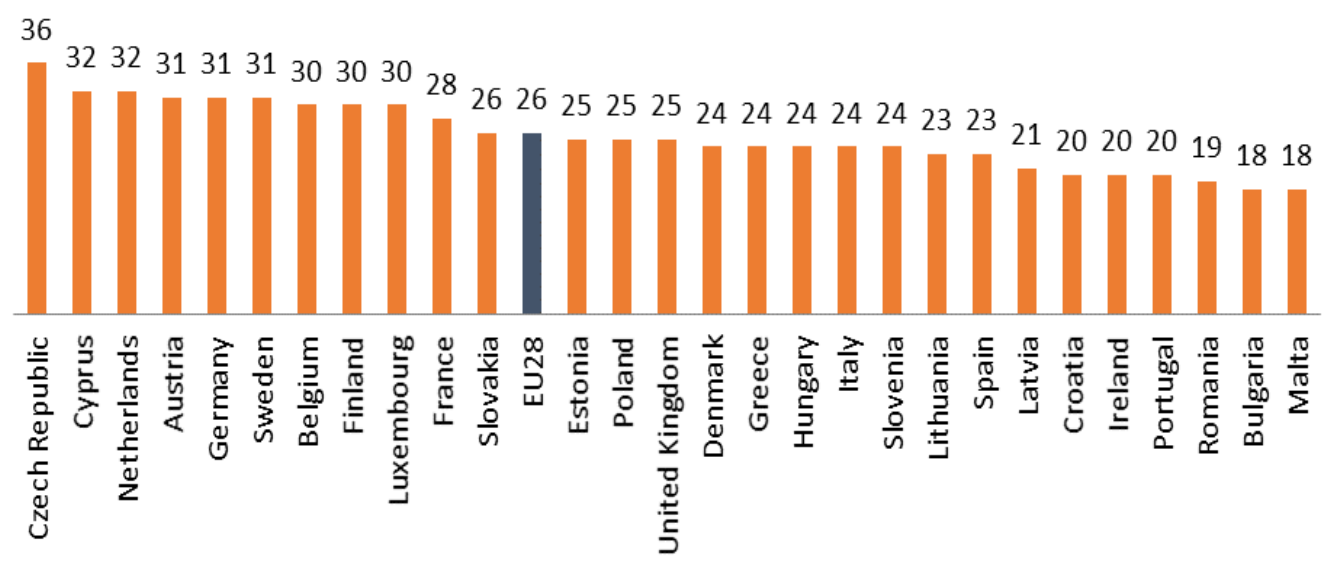

Figure 2. Overall basic digital skills in the EU28 in 2017 (percentage of population)

(Source: (Eurostat, 2018a))

The ICT skills (digital, computer, internet) are obtained through formalised education (school, college, university, etc), through training courses and adult education centres, on own initiative or on demand from the employer, through self-study using books, cd-roms, etc. or through informal assistance from colleagues, relatives in friends and some other ways. In $2011^{1}$, most of the individuals in the EU 28 obtained their IT skills through formalised education (i.e. $28 \%$ of all individuals), followed by training through self-study using books, cd-roms, etc ( $21 \%$ of all individuals). The training courses and adult education centres at own initiative and at the demand of the employer were used in almost equal shares $(13 \%$ and $14 \%$ of total population) (Eurostat, 2011). Analysing the status in the workforce of persons with ICT education and training, regardless of the level of education attained and ICT/digital skills obtained, Germany has the highest number of persons with ICT education active \& employed, followed by the United Kingdom, Poland and France (Eurostat, 2018b) (Figure 3.

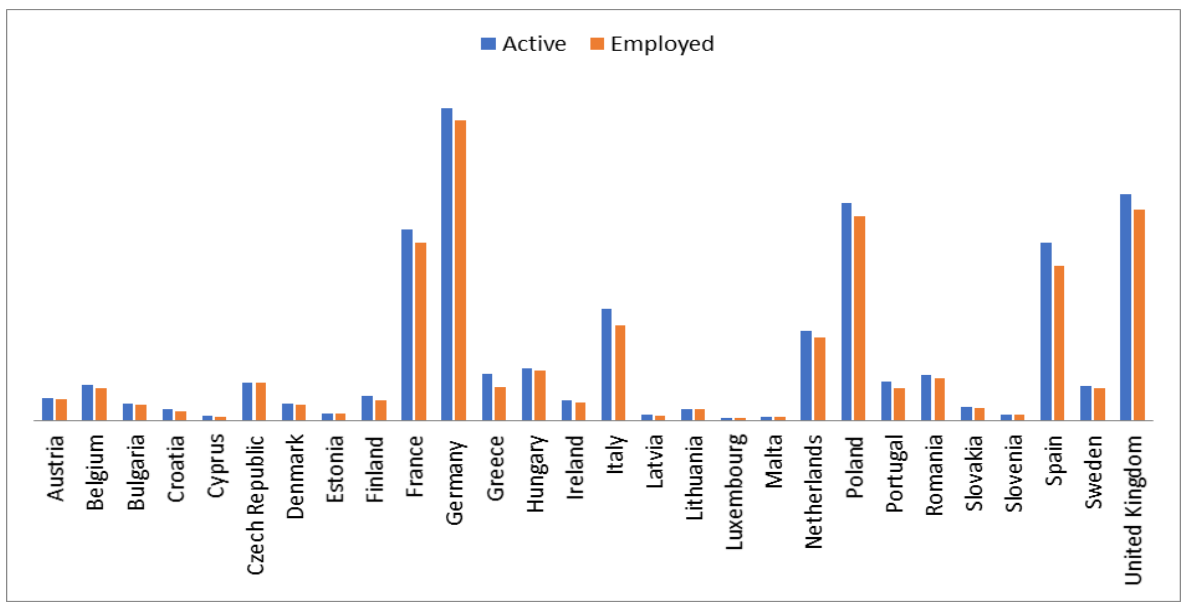

12011 is the last year for which there are recordings in the Eurostat database for this indicator (Eurostat, 2011) 
Figure 3. Persons with ICT education active and employed, regardless of the level of education and digital skills (Source: (Eurostat, 2018b))

\section{Human capital with advanced and specialist digital skills in the ICT in the EU 28}

Advanced digital activities (and corresponding digital skills) are mainly related to the use software for design, calculation or simulation, programme and use CNC machines and programme and use robots, whilst specialist digital activities (and skills) refer to undertake programming and software development and design and maintain ICT architecture for the workplace (European Commission, 2017). With few exceptions, almost all EU28 countries increased their percentage of individuals having above digital skills (advanced and specialist) over 2015-2017, with top performers in 2017 Luxembourg, Netherlands and Denmark (Eurostat, 2018a).

The data about advanced and specialist digital skills is generally consistent with the graduates in the fields of information and communication technologies (ICT) in the EU28, including computer use, database and network design and administration, software and applications development and analysis, and inter-disciplinary programmes and qualifications involving information and communication technologies (according to ISCED-F-2013 fields of education and training) (UNESCO - Institute for Statistics, 2015). In 2015', the EU 28 countries with the highest percentage of advanced and specialist ICT tertiary graduates from the total number of tertiary graduates (ISCED 11, levels 5-8, (UNESCO - Institute for Statistics, 2012)) were Malta, Finland, Ireland, Romania (Eurostat, 2017c) (Table 2). It is, however, interesting to observe that although they have a high percentage of ICT tertiary graduates, Malta, Romania, Ireland are not very high when it comes about the actual advanced and specialist digital skills (see Table 2 and Figure 3 ). A possible explanation for this fact is that there is a mismatch between the ICT skills provided by the high education institutions and those required and employed later on in the workplace.

Table 2. Total tertiary graduates, tertiary graduates in ICT as part of total tertiary graduates (ISCED 2011, levels 58) and persons employed in ICT / digital specialist positions in the EU28 countries.

(Source: (Eurostat, 2017c))

\begin{tabular}{|l|l|l|l|l|l|l|}
\hline & $\begin{array}{l}\text { Population } \\
\mathbf{2 0 1 5}\end{array}$ & $\begin{array}{l}\text { Total number } \\
\text { of tertiary } \\
\text { graduates } \\
\text { (thousand) } \\
\mathbf{2 0 1 5}\end{array}$ & $\begin{array}{l}\text { Total number } \\
\text { of tertiary } \\
\text { graduates in } \\
\text { ICT (thousand) } \\
\mathbf{2 0 1 5}\end{array}$ & $\begin{array}{l}\text { Percentage of } \\
\text { ICT tertiary } \\
\text { graduates from } \\
\text { total graduates } \\
\mathbf{2 0 1 5}\end{array}$ & $\begin{array}{l}\text { Employed } \\
\text { ICT } \\
\text { specialists } \\
\text { (thousand) } \\
\mathbf{2 0 1 5}\end{array}$ & $\begin{array}{l}\text { Employed ICT } \\
\text { specialists } \\
\text { (thousand) } \\
\mathbf{2 0 1 6}\end{array}$ \\
\hline Austria & 8576261 & 83587 & 3358 & 4.0 & 166.6 & 178.6 \\
\hline Belgium & 11208986 & 112406 & 1229 & 1.1 & 188.4 & 193.8 \\
\hline Bulgaria & 7202198 & 62718 & 1957 & 3.1 & 69.6 & 80.9 \\
\hline Croatia & 4225316 & 36144 & 1467 & 4.1 & 42.7 & 52.3 \\
\hline Cyprus & 847008 & 7941 & 240 & 3.0 & 7.9 & 7.9 \\
\hline Czech Republic & 10538275 & 98119 & 3848 & 3.9 & 184.6 & 180.9 \\
\hline Denmark & 5659715 & 74428 & 3246 & 4.4 & 106.4 & 119.4 \\
\hline Estonia & 1313271 & 10491 & 516 & 4.9 & 28.5 & 34.1 \\
\hline Finland & 5471753 & 56829 & 3784 & 6.7 & 157.7 & 162.3 \\
\hline France & 66415161 & 752068 & 23012 & 3.1 & 950.1 & 1003.8 \\
\hline Germany & 81197537 & 544743 & 24755 & 4.5 & 1465.6 & 1541.1 \\
\hline Greece & 10858018 & Not available & Not available & Not available & 43.7 & 51.2 \\
\hline Hungary & 9855571 & 68485 & 1620 & 2.4 & 152.6 & 158.1 \\
\hline Ireland & 4628949 & 67303 & 4355 & 6.5 & 72.4 & 78.1 \\
\hline Italy & 60795612 & 368533 & 11451 & 3.1 & 558.3 & 584.8 \\
\hline Latvia & 1986096 & 17021 & 752 & 4.4 & 19.4 & 19.7 \\
\hline Lithuania & 2921262 & 32205 & 587 & 1.8 & 27.9 & 34.1 \\
\hline Luxembourg & 562958 & 2054 & 96 & 4.7 & 12.0 & 10.8 \\
\hline Malta & 429344 & 3953 & 335 & 8.5 & 6.7 & 7.1 \\
\hline Netherlands & 16900726 & 148942 & Not available & Not available & 412.7 & 422.2 \\
\hline
\end{tabular}

${ }^{1}$ At the time of the research, 2015 was the last year with recorded data available in Eurostat, (Eurostat, 2017c). No data was available for Greece and Netherlands. 


\begin{tabular}{|l|l|l|l|l|l|l|}
\hline & $\begin{array}{l}\text { Population } \\
\mathbf{2 0 1 5}\end{array}$ & $\begin{array}{l}\text { Total number } \\
\text { of tertiary } \\
\text { graduates } \\
\text { (thousand) } \\
\mathbf{2 0 1 5}\end{array}$ & $\begin{array}{l}\text { Total number } \\
\text { of tertiary } \\
\text { graduates in } \\
\text { ICT (thousand) } \\
\mathbf{2 0 1 5}\end{array}$ & $\begin{array}{l}\text { Percentage of } \\
\text { ICT tertiary } \\
\text { graduates from } \\
\text { total graduates } \\
\mathbf{2 0 1 5}\end{array}$ & $\begin{array}{l}\text { Employed } \\
\text { ICT } \\
\text { specialists } \\
\text { (thousand) } \\
\mathbf{2 0 1 5}\end{array}$ & $\begin{array}{l}\text { Employed ICT } \\
\text { specialists } \\
\text { (thousand) } \\
\mathbf{2 0 1 6}\end{array}$ \\
\hline Poland & 38005614 & 516675 & 15,744 & 3.0 & 423.7 & 431.8 \\
\hline Portugal & 10374822 & 74757 & 862 & 1.2 & 104.3 & 108.8 \\
\hline Romania & 19870647 & 133478 & 7142 & 5.4 & 160.8 & 167.7 \\
\hline Slovakia & 5421349 & 61054 & 1752 & 2.9 & 68.1 & 73.2 \\
\hline Slovenia & 2062874 & 18631 & 647 & 3.5 & 32.9 & 32.1 \\
\hline Spain & 46449565 & 438616 & 17345 & 4.0 & 426.8 & 557.6 \\
\hline Sweden & 9747355 & 78244 & 2758 & 3.5 & 293.8 & 310.8 \\
\hline United Kingdom & 64875165 & 740276 & 26741 & 3.6 & 1542.1 & 1608.2 \\
\hline
\end{tabular}

Advanced and specialist ICT / digital jobs and activities in organisations in the EU28 are considered, for example, the maintenance of ICT infrastructure, the support for office software, the development of business management software/systems, the development of web solutions, the security and data protection (Eurostat, 2017d). In order to have an image of what happens with the ICT specialist graduates after they finalise their studies (ISCED 2011, levels 5-8), the number of total ICT tertiary graduates in 2015 was compared with the number of total persons employed in ICT specialist positions in organisations across EU28 in 2016. The comparison serves only to provide a broad image of the flow of ICT tertiary graduates into the labour market, since there exists no clear correlation in the EU28 between graduates and their place of employment after graduation. A more correct comparison can be made when referring to the total population per country (Eurostat, 2017c) (Eurostat, 2017d). It is noticeable that the number of jobs requiring advanced and specialist ICT/digital skills, and persons employed, increased from 2015 to 2016 in almost all EU28 countries Table 2). The highest increase in the number of advanced and specialist ICT/digital jobs in 2016 compared to 2015 was registered in Spain (almost 131000 more people employed as ICT specialists in 2016 compared to 2015), followed by Germany (about 76000 more ICT specialists employed in 2016), United Kingdom (about 66000 more ICT specialists) and France (about 54000 more ICT specialists) (Table 2). Compared to the total population, the EU28 countries with the highest percentage of employed ICT specialists in 2016 were Sweden, Finland, Estonia, Netherlands, United Kingdom, Austria and Denmark, whilst Cyprus, Romania and Greece are the countries with the least ICT specialists employed compared to the total population. In general, it can be noted that there much fewer persons employed in ICT / digital specialist jobs than the number of ICT tertiary graduates, ISCED 2011, levels 5-8. For example, United Kingdom has the highest number of ICT tertiary graduates in 2015 in the EU28 (i.e. 26741000 persons), however the total number of people employed in ICT/digital specialist jobs in 2015 (which include ICT tertiary graduates of other years as well) was only 1542100 individuals. If to correlate broadly the number of ICT tertiary graduates in 2015 with the number of persons employed in ICT/digital specialist positions, it can be noted that the countries that employ most of their ICT tertiary graduates in specialist ICT jobs are Belgium, Luxembourg, Portugal, Sweden and Hungary (Table 2). EU28 countries that do not appear to make good use of their ICT tertiary graduates by employing them in ICT/digital specialist jobs are Ireland, Malta, Romania, Spain, Poland and Croatia.

\section{Evolution of the digital competitiveness of the EU 28 member states from the perspective of human capital over the period 2014-2017}

In 2014, the European Commission launched the Digital Economy and Society Index (DESI) as a composite index of five main indicators deemed relevant for assessing European Union performance in digital competitiveness (European Commission, 2014-2017). The structure of the composite DESI is presented in Figure 4.

\section{Figure 4. The structure of the Digital Economy and Society Index}

(Source: (European Commission, 2014-2017)

For the dimension Human Capital, the European Commission composite DESI measures the Basic skills and usage (including the indicators "Internet users: Individuals whose frequency of Internet access is at least once a week", and "Basic Digital Skills: Individuals with basic or above basic digital skills") and the Advanced skills and development (including the 
indicators "ICT Specialists: Persons Employed with ICT Specialist Skills" and "STEM Graduates: Science and technology graduates").

The number of individuals with basic and advanced skills increased in almost all EU28 countries from 2014 to 2017. However, there are countries that are consistently top performers over this period of time for both basic and advanced digital skills (i.e. Luxembourg, Netherlands, Denmark, Finland, United Kingdom, Sweden), and countries that over 20142017 are always the last in this ranking, with about 10-15\% (sometimes less) of individuals having basic and/or advanced digital skills (the case of Bulgaria and Romania) (European Commission, 2014-2017) (Figure 5).

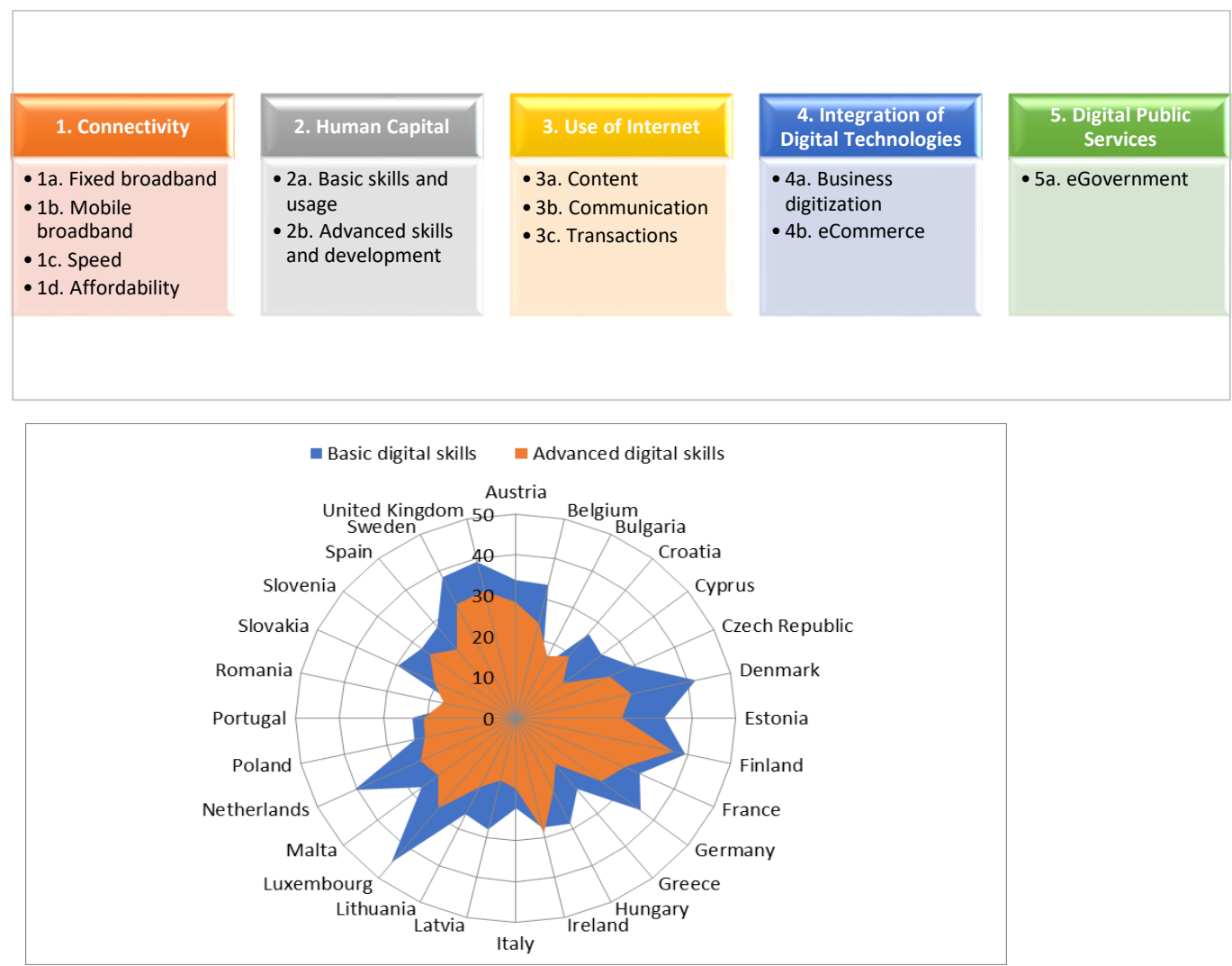

Figure 5. The digital competitiveness of the EU 28 member states from the perspective of human capital over the period 2014-2017

(Source: (European Commission, 2014-2017))

\section{Conclusions}

The EU 28 countries with the highest number of individuals with basic digital skills during $2015-2017$ (over 30\% of individuals) are Czech Republic, Cyprus, Netherlands, Austria, Germany, Sweden.

The EU28 countries with the highest number of individuals with advanced / specialist digital skills in 2015 (over $45 \%$ of individuals) are Luxembourg, Netherlands, Denmark, Sweden, United Kingdom, Finland.

The EU28 countries with the highest number of ICT tertiary graduates in 2015 (no further data available; no data available for Greece and Netherlands) are United Kingdom, Germany, France, Spain, Poland, Italy. 
The EU 28 countries with the highest number of persons employed in ICT / digital advanced and specialised jobs in 20152016 are United Kingdom, Germany, France, Italy, Netherlands, Poland.

Looking at the combined data analysed in the paper, the most performant EU28 countries in terms of digital competitiveness from the perspective of human capital during 2014-2017 are United Kingdom, Netherlands, Germany. Although they have a high number of ICT tertiary graduates, countries such as Bulgaria and Romania fail at employing them nationally in ICT/digital specialised jobs. In addition, despite the high number of ICT graduates, these countries do not perform in terms of basic or advanced digital skills of individuals, being found consistently at the lower end of the digital competitiveness scale from the perspective of human capital over 2014-2017.

\section{Footnotes:}

${ }^{1}$ Computer numerical control (CNC), https://en.wikipedia.org/wiki/Numerical_control

22011 is the last year for which there are recordings in the Eurostat database for this indicator (Eurostat, 2011)

${ }^{3}$ At the time of the research, 2015 was the last year with recorded data available in Eurostat, (Eurostat, 2017c). No data was available for Greece and Netherlands.

\section{Bibliography}

[1] Burton, P. (2015). The Importance of Digital Skills in the Modern Workplace. Retrieved January 15, 2018, from Skills you need: https://www.skillsyouneed.com/rhubarb/digital-skills-modern-workplace.html

[2] Cedefop. (2015). Skills, qualifications and jobs in the EU: the making of a perfect match? Evidence from Cedefop's European skills and jobs survey. . Luxembourg: Publication Office of the European Union.

[3] Chinien - Boutin. (2013). Definition of Digital Skills. Retrieved January 15, 2018, from Rewired for technology: http://www.rewired4technology.com/286/

[4] Development Economics. (2013). The Future Digital Skills needs of the UK Economy. . Development Economics.

[5] Digital Technology. (2017). The Top 10 Digital Skills Tech Companies are Looking for Today. Retrieved January 15, 2018, from Digital Skills Academy: https://digitalskillsacademy.com/blog/the-top-10-digital-skillstech-companies-are-looking-for-today

[6] Ecorys UK. (2016). Digital skills for the UK economy.

[7] European Commission. (2010). A Digital Agenda for Europe. Retrieved January 15, 2018, from EUR-Lex: http://eur-lex.europa.eu/legal-content/en/ALL/?uri=celex\%3A52010DC0245

[8] European Commission. (2014-2017). The Digital Economy and Society Index (DESI). Retrieved January 15, 2018, from Policies-Digital Single Markey: https://ec.europa.eu/digital-single-market/en/desi

[9] European Commission. (2016). Europe's digitall progress report. Brussels: European Commission.

[10] European Commission. (2017). E-skills for the 21st century: fostering competitiveness, growth and jobs. . Retrieved January 15, 2018, from EUR-Lex: http://eur-lex.europa.eu/legalcontent/EN/TXT/?uri=celex:52007DC0496

[11] European Commission. (2017). ICT for work. Digital skills in the workplace. Brussels: European Commission.

[12] European e-Competenece Framework. (2016). A common European framework for ICT Professionals in all industry sectors. Retrieved January 15, 2018, from e-CF: http://www.ecompetences.eu/

[13] European Parliament and Concil of the EU. (2006). Recommendation of the European Parliament and of the Council of 18 December 2006 on key competences for lifelong learning. Retrieved January 15, 2018, from EUR-Lex: http://eur-lex.europa.eu/legal-content/EN/TXT/?uri=celex\%3A32006H0962

[14] Eurostat. (2011). Way of obtaining e-skills. Retrieved January 15, 2018, from Eurostat: http://appsso.eurostat.ec.europa.eu/nui/show.do?dataset=isoc_sk_how_i\&lang=en

[15] Eurostat. (2017a). Individuals' level of computer skills. Retrieved January 15, 2018, from Eurostat: http://appsso.eurostat.ec.europa.eu/nui/show.do?dataset=isoc_sk_cskl_i\&lang=en

[16] Eurostat. (2017b). Individual's level of internet skills. Retrieved January 15, 2018, from Eurostat: http://appsso.eurostat.ec.europa.eu/nui/show.do?dataset=isoc_sk_iskl_i\&lang=en).

[17] Eurostat. (2017c). Graduates by education level, programme orientation, sex and field of education . Retrieved from Eurostat: http://appsso.eurostat.ec.europa.eu/nui/show.do?dataset=educ_uoe_grad02\&lang=en 
[18] Eurostat. (2017d). Employed ICT specialists. Retrieved January 15, 2018, from Eurostat: http://appsso.eurostat.ec.europa.eu/nui/show.do?dataset=isoc_sks_itspt\&lang=en

[19] Eurostat. (2018a). Individual's level of digital skills. Retrieved from Eurostat: http://appsso.eurostat.ec.europa.eu/nui/show.do?dataset=isoc_sk_dskl_i\&lang=en

[20] Eurostat. (2018b). Persons with ICT education by labour status . Retrieved January 15, 2018, from Eurostat: http://appsso.eurostat.ec.europa.eu/nui/show.do?dataset=isoc_ski_itemp\&lang=en

[21] Ferrari, A. (2013). DIGCOMP: A Framework for Developing and Understanding Digital Competence in Europe. Luxembourg, Publications Office of the European Union: European Commission Joint Research Centre, Institute for Prospecting Technological Studies.

[22] J. Fraillon, W. Schulz, J. Ainley. (2013). International Computer and Information Literacy Study- An Assessment Framework. The Australian Council for Educational Research.

[23] K.A.Mutka. (2011). Mapping Digital competence- Towards a Conceptual understanding. Luxembourg, Publishing Office of the European Union: Joint Research Center- Institute for Prospective Technology Studies.

[24] L. Ilomaki, A. Kanotsalo, M. Lakkala. (2011). What is digital competence? Linked portal. Brussels: European Schoolnet.

[25] M. Kolding, C. Robinson, M. Ahorlu. (2009). Post Crisis: e-Skills are needed to drive Europe's Innovation Society. London: White Paper - IDC Opinion. IDC EMEA.

[26] OECD. (2004). The ICT productivity paradox- evidence from micro data. OECD Economic Studies. No. 38. Paris: OECD Publlishing.

[27] OECD. (2013). OECD Skills Outlook 2013: First Results from the Survey of Adult Skills. Paris: OECD Publishing.

[28] OECD. (2016). New Skills for the Digital Economy: Measuring the Demand for ICT Skills at Work. OECD Digital Economy Papers No. 258. Paris: OECD Publishing.

[29] R. Vuorikari, Y. Punie, S. Carretero, L. Van den Brande. (2016). DigComp 2.0: The Digital Competence Framework for Citizens. Update Phase 1: The Conceptual Reference Model. Luxembourg, Publication Office of the Euroepan Union: Joint Research Centre.

[30] S. Carretero, R. Vuorikari, Y. Punie. (2017). DigComp 2.1: The Digital Competence Framework for Citizens with eight proficiency levels and examples of use. . European Commission. EU Science Hub.

[31] The Tech Partnership. (2017). Basic digital skills framework. Retrieved January 15, 2018, from The Tech Partnership: https://www.thetechpartnership.com

[32] UKforCE. (2014). Digital Skills Taskforce call for evidence: Submission from the UK forum for Computing Education (UKforCE). . UK forum for Computing Education: Cited in Ecorys UK 2016.

[33] UNESCO - Institute for Statistics. (2012). ISCED 2011. International Standard Classification of Education. Montreal: UNESCO-UIS.

[34] UNESCO - Institute for Statistics. (2015). ISCED-F 2013. International Standard Classification of Education. Montreal: UNESCO-UIS.

[35] Y. Eshet-Alkalai, E. Chajut. (2010). You can teach old dogs new tricks: The factors that affect changes over time in digital literacy. . Journal of Information Technology Education, 173-181.

Tables:

Table 1. Conceptual frameworks for digital skills

Table 2. Total tertiary graduates, tertiary graduates in ICT as part of total tertiary graduates (ISCED 2011, levels 5-8) and persons employed in ICT / digital specialist positions in the EU28 countries.

Figures:

Figure 1. Overall digital skills of individuals in the EU28 in 2017 (percentage of population)

Figure 2. Overall basic digital skills in the EU28 in 2017 (percentage of population)

Figure 3. Persons with ICT education active and employed, regardless of the level of education and digital skills

Figure 4. The structure of the Digital Economy and Society Index

Figure 5. The digital competitiveness of the EU 28 member states from the perspective of human capital over the period 2014-2017 